\title{
ARE ACCOUNTING STUDENTS INTERESTED IN BECOMING ACCOUNTPRENEURS? A FUTURE CAREER SURVEY IN GREATER JAKARTA
}

\author{
Rusmanto Toto \\ Department of Accounting, Faculty of Economics and Communications, \\ University of Bina Nusantara, Jakarta, Indonesia \\ E-mail: trusmanto@binus.edu
}

\begin{abstract}
Accountpreneur is a term referred to those who have accounting background and become entrepreneurs. This study aims to investigate accounting students intention to become entrepreneur in their future (called as accountpreneur), or to become public accountant or other profession. This study also identify some important skills that must be possessed or needed by students to support their future career, This study using survey method on accounting students in Greater Jakarta from 10 Universities in Jakarta. Data collected are tabulated and analysed using descriptive statistic. The study found that from 411 students participated in this survey, 101 students $(25 \%)$ are willing to become accountpreneurs. While 90 students $(22 \%)$ choose to become public accountants and 220 students (53\%) the rest choose other various profession. The study also reveals five skills most needed by students to support their future career. These skills are: adaptability, communication, accounting software/technology, data analytics and English.
\end{abstract}

\section{KEY WORDS}

Accountpreneurs, accounting students, Greater Jakarta, accounting profession.

Entrepreneurship has a very important role in encouraging national economic development, starting from creating new job opportunities, creating added value for goods \& services, reducing economic \& social disparities, until creating a prosperous society. Entrepreneurship, which acts as a driving force for the nation's economy, became one of the main keys in maintaining the sustainability and welfare of a country. Apart from the importance of entrepreneurship, not many people are interested in taking part of it, especially in Indonesia. This is why Indonesian government is trying to encourage Indonesian citizens to become entrepreneurs as early as possible, especially for the younger generation. The government sees that Indonesian students have higher creativity and innovation than the previous generation which makes them possible in becoming successful entrepreneurs. But in reality, many students choose to have permanent and stable jobs after graduating than to become entrepreneurs. This is no exception for accounting students. Starting from the absence of business capital to the fear of failure, became the reason why many students does not have interest in becoming entrepreneurs. According to Bidin et al. (2012), accounting students are not interested in becoming entrepreneurs because of the hardship involved and the possibility of failure in starting a business which made them prefer to work in a public or private sector job.

The expected role of higher education is not only to graduate the generation of job seekers, but also to be able to produce graduates who are able to create jobs or entrepreneurship. The lack of interest in accounting students to become entrepreneurs shows that universities have not yet fulfil its expected role. This is clearly unfortunate because based on a study conducted by Hanif et al. (2019), accounting is one of the skills that an entrepreneur must have in order to succeed. This means that accounting students have a very big opportunity to become successful entrepreneurs in the future.

On the other hand, the Indonesian Institute of Certified Public Accountants (IAPI) revealed that Indonesia lacks public accountants and still needs this profession in large numbers. In 2019, Indonesia only has 4,000 CPA (Certified Public Accountant) holders while in other countries like Thailand already has 12,000 CPA holders. 
From the phenomena above stating that accounting students have a competency to become entrepreneur and the lack of intention to become accountants, then the author intend to answer the following main research question "Are Accounting Students Interested in becoming Accountpreneurs?".

The purpose of the research is to know: (i) how big accountings students' intention to become entrepreneurs; (ii) How big accounting students intention to become public accountants; (iii) How big accounting intention students to become other professions; (iv) What skills that actually needed by accounting students to support their career in the future?

\section{LITERATURE REVIEW}

According to Timmons \& Spinelli (2004), entrepreneurship is a way of thinking, studying, and acting based on a balanced business opportunity, holistic approach and leadership. While Saragih (2017) defined entrepreneurship as the ability to create something new and different through creative thinking and innovative actions for the creation of opportunities. In study conducted by Chotimah (2014), entrepreneurship is defined as a creative and innovative ability that is used as a basis, tips and resources to seek and take advantage of opportunities for success. People who owned their own business are called entrepreneurs (Hadiyati, 2011). Being an entrepreneur means having the will and ability to find and evaluate opportunities, gather the necessary resources and act to take advantage of those opportunities. They take calculated risks and like challenges with moderate risks. Entrepreneurs believe and stick to themselves and their ability to make the right decisions. The ability to make decisions is the characteristic of entrepreneurs.

Raimi (2016) defined accountpreneur as someone who has an accounting background and becomes an entrepreneur. An accountpreneur not only has the ability to produce and analyze financial reports, but also has the ability to be entrepreneurial. Accountpreneurs are self-appointed, self-reliant, self-sufficient, and self-employed. They need to have right attitude about businesses, strong inner drive, self-confidence, healthy opinion, assertiveness, possessing new innovations, openness in adopting change, eagerness to learn new things, competitiveness in all pursuits, energetic, self-motivated, accept constructive criticism, and willingness to improvise.

Besides being an accountpreneur, one of the jobs that is familiar to accounting students is being a public accountant. Ulfah et al. (2019) defined a public accountant as a person who examine public accounting services and has completed the absolute have a Certified Public Accountant (CPA) degree. CPA is a certification for the profession of public accountants or financial report auditors. Public accountants are indeed play important role for development of business activities, but there are public accountants who managed to become successful entrepreneurs and one of them is Phil Knight. Knight is a Certified Public Accountant (CPA) and co-founder of Nike. Forbes ranked Knight as the 21st richest person in the world as of October 2019, with an estimated net worth of US $\$ 37.6$ billion. He also owns the stop motion film production company Laika (Trending Accounting, 2019). This shows that accounting students have a high chance in becoming successful accountpreneurs. The only problem is whether they have the interest in doing it or not.

The following parts of this section will discuss some factors that can affect accounting students' intention in becoming accountpreneurs.

Nightingale (2002) defined gender as "the socially constructed differences between biological males and females" while the American Psychological Association (2012) define gender as "the attitudes, feelings, and behaviors that a given culture associates with a person's biological sex". In previous study conducted by Lysons \& Madura (2016), stated that even though the difference among men and women was not significant, men did rate higher on entrepreneurial intention compared to women. This finding also supported by Camelo et al. (2016) who found that women have lower perception regarding their abilities to succeed in entrepreneurial tasks. This means that women tend to develop lower entrepreneurial intention compared to men. According to Anna et al. (2000), women perceive themselves 
having a less efficacy in relation to entrepreneurial activities, less capability for recognizing entrepreneurial opportunities, and feel more fear to failure, than men. This perception will eventually constrain their entrepreneurial intention. The research of García \& Cañizares (2010) also reported that female students perceived the possibility of failure is the most important obstacle in starting a business their male counterparts noted other aspects such as tax burdens or personal effort.

Previous study also found that gender not only affect entrepreneurial intention but also affect accounting students' interest in having a career as public accountant and non-public accountant (Dary \& llyas, 2017). This research shows that gender has a significant influence on career choices to become a public accountant and it has a very important impact on every activity carried out by humans. Most men choose to become public accountant, while women choose non-public accounting profession. This can be due to the perspective that women are not that good as public accountants, seen from the type of work that can take up women's time to take care of their families.

In a study conducted by Ariyanto \& Wiratno (2013), it was found that an understanding of accounting has an influence in starting a business, while Nurbaeti et al. (2019) found that accounting knowledge is not used as a factor that can make it easier or difficult for someone to adopt a new business. Since these two previous studies are contradictory to each other, there has to be a further research in order to verify the relationship between accounting knowledge and accounting student's entrepreneurial intention.

Accounting knowledge not only influence students' entrepreneurial intention, but also influence their intention in becoming public accountant. In study conducted by Jessica et al. (2019) accounting students with higher GPA and longer period of study has more positive attitude towards working as a public accountant compared to other accounting students. Another study also found that intention to be a public accountant may fluctuate during students' study terms in universities (McDowall \& Jackling, 2010). This may due to the public accountant profession that requires a correct and deep understanding of accounting knowledge. Therefore, accounting knowledge on the intention to work in public-accountingrelated profession is crucial to maintain public accounting professional sustainability.

Many studies showed that parent's entrepreneurial background positively affecting students' entrepreneurial intention (Fatoki, 2018; Nurrahmah \& Aisyah, 2018; Saeed et al., 2014). Previous studies have shown that having a parent who is an entrepreneur will increase the child's in becoming an entrepreneur as well (Altinay et al., 2012; Carr \& Sequeira, 2007; Hisrich \& Brush, 1984; Krueger, 1993). This may be due to the tendency of a child imitate their parent's values, attitudes, and behaviour. With that being said, public accountant parents should have indirectly influenced their children in becoming a public accountant as well. But since there are only a few studies adressing this matter, further research is needed to determine whether parents who work as public accountant really influence their children in becoming public accountants as well.

Previous studies showed that external parties such as family members and important people around play a big part in encouraging accounting students' entrepreneurial intention (Bidin, et al. 2012; Lyons \& Bandura, 2016; Reyad et al. 2018; Nurrahmah \& Aisyah, 2018). Most accounting students believed that family members and people around them played a big role in encouraging them to get involved in entrepreneurship. They also often have substantial influence over their career choices and decisions including in becoming an entrepreneur or a public accountant. Directly or indirectly, people around them, especially parents, strongly influence a child's decision in selecting a career.

According to Kogan et al. (2018), "risk tolerance refers to the ability to withstand painful or critically negative assessments of one or more non-hazard components". Despite all efforts that were made to lessen those negative assessments, students are not interested in becoming entrepreneurs due to the hardships involved and the perception of failure in starting a business (Bidin et al., 2012). Bidin et al., (2012) also mentioned that students having a bad perception about starting a business will be less likely to develop an entrepreneurial intention. Similar findings also found by Nurrahmah \& Aisyah (2018) who 
found that student's entrepreneurial intention is positively affect by risk tolerance or their courage to take risks.

According to Delgado \& Valencia (n.d.) students who receive entrepreneurial education are more likely to become entrepreneurs than other students. They also stated that it is very important for universities to create programs or courses which can motivate students' entrepreneurial attitude which can increase their interest in starting their own business. Those entrepreneurial program or courses will give them a certainty of professional achievement. Another study also showed that academic environment and education is one of the major keys in the preparing accounting students in starting up a business and become successful entrepreneurs (Reyad et al., 2018). This means that university curriculum and the entrepreneurial skills of the accounting students are highly dependent on each other and are further developed by the opportunities offered by the labour market.

Independency refers to the capability to decide and determine for oneself what to do (Kyndt \& Baert, 2015). Independency also refers to an individual's desire for freedom, control, and flexibility in using their time (Carter et al., 2003). According to Nurrahmah \& Aisyah (2018), independency positively influence accounting students' entrepreneurial intention. The independence of a person will form from the desire not to rely on others, but rather to optimize all of its resources and efforts. One of the factors that influence entrepreneurial intention of an individual is a boost to be able to compete with others. Douglas \& Shepherd (2002) stated that the difference between entrepreneurs and nonentrepreneurs is that entrepreneurs are characterized as independence-seekers who has a high need for independence. They tend to have a strong reason for staring a new business.

In accounting, there is a term known as capital. Capital in this context means venture capital. Venture capital is needed in every business to start and run its operation. Starting from the equipment and supplies needed, to the amount of funds needed for business to progress. Without capital, a business cannot run. Thus, capital is needed to start a business. According to Ariyanto \& Wiratno (2013) business capital is more important than the students' level of confidence in increasing their entrepreneurial intention. If there is not enough business capital, it is impossible to start a business, therefore the students' intention in becoming an entrepreneur decrease. Availability of capital creates favourable conditions for the entrepreneur which greatly affects the interest in entrepreneurship (Hurley 1999). Despite the fact there are some people who start businesses without capital.

In a study conducted by Bidin et al. (2012), accounting students may eventually venture into the entrepreneurial field after gaining some kind of working experience and confidence in starting up their own business. The study also found that this kind of cycle is common for most new graduates since they do not have any practical experience and might feel more comfortable working for an organization before starting their own business. The same finding also found by Lyons \& Bandura (2016) that accounting graduates may start their own business after attain some experience in the profession. This may due to the influence of their accounting faculty and/or accounting professionals who told them not to think about starting a business but rather to commence a career in the employ of a respected accounting firm.

\section{METHODS OF RESEARCH}

This research used survey method which uses primary data sources in the form of online questionnaires filled out by accounting students from 10 universities in Greater Jakarta area. The primary aim of the questionnaire is to examine the perception of the accounting students in greater Jakarta area in relation to their intention to become entrepreneurs, public accountants or other profession in their future career. The sampling technique used in this research is purposive random sampling. Researchers distributed the online questionnaire's link only to active accounting students from universities in Greater Jakarta area.

Descriptive statistic and analysis were used in analysing the data. Respondents were asked to choose their future career. Whether they want to be accountpreneurs, public 
accountants or othe profession. Respondent also asked to mention what kind of skill they needed to support their future career.

As tabulated on the table 1. the number of respondents in this research was 411 students which includes 201 students from Sekolah Tinggi Ilmu Ekonomi Indonesia Rawamangun, 84 students from Bina Nusantara University Bekasi, 48 students from Universitas Muhammadiyah, 37 students from Universitas Yarsi, 13 students from Politeknik Negeri Jakarta, and 28 students from other universities in Greater Jakarta area.

\section{RESULTS AND DISCUSSION}

On the table 3, it can be seen that from all 411 accounting students in Greater Jakarta area, there are 101, which includes 24 male and 77 female students, who are interested in becoming an accountpreneurs. This means that $25 \%$ of respondents are willing to be accountpreneurs in their future career. This finding is quite good and promising since the intention of Indonesian people is low to become entrepreneurs. Accounting students are expected to become successful accountpreneurs as they have business competency and skill in running their business.

Meanwhile, there are only 90 students, which includes 19 male and 71 female students, who are interested in becoming a public accountant. This means that there are only $22 \%$ of respondents wo are willing to become public accountants in their future career. From this fact, it can be seen that more female students are willing to become public accountants. But this can happen because the number of accounting students are normally dominated by female students as this happen in this survey. Most respondents are female as presented on the table 2. This finding contradicts with the study of Dary and llyas (2017). However, this is good news since the number of Public Accountants as discussed earlier are insufficient.

Table 1 - Respondents Universities of Origin

\begin{tabular}{|l|l|l|}
\hline Universities & Number of Respondents & Percentage (\%) \\
\hline STEI Jakarta & 201 & 49 \\
\hline Bina Nusantara & 84 & 20 \\
\hline Muhammadiyah University & 48 & 12 \\
\hline Universitas Yarsi & 37 & 9 \\
\hline Politeknik Negeri Jakarta & 13 & 3 \\
\hline Others Universities & 28 & 7 \\
\hline TOTAL & 411 & 100 \\
\hline
\end{tabular}

Table 2 - Respondents Gender

\begin{tabular}{|l|l|l|}
\hline Gender & Number of Respondent & Percentage (\%) \\
\hline Male & 89 & 22 \\
\hline Female & 322 & 78 \\
\hline TOTAL & 411 & 100 \\
\hline
\end{tabular}

Table 3 - Students' Career Choice

\begin{tabular}{|l|l|l|l|l|}
\hline $\mathrm{n} / \mathrm{n}$ & Accountpreneurs & Public Accountants & Other Profession & \\
\hline Male & 24 & 19 & 46 & 89 \\
\hline Female & 77 & 71 & 174 & 322 \\
\hline TOTAL & $101(25 \%)$ & $90(22 \%)$ & $220(53 \%)$ & 411 \\
\hline
\end{tabular}

Table 4 - Top Five Skills Needed by Students for Future Research

\begin{tabular}{|l|l|l|}
\hline No & Skills Needed & Chosen by Students \\
\hline 1. & Adaptability Skill & 239 \\
\hline 2. & Communication Skill & 223 \\
\hline 3. & Accounting Software Skill & 221 \\
\hline 4. & Data Analytics Skill & 204 \\
\hline 5. & English Skill & 184 \\
\hline
\end{tabular}


While more than half of respondents or $53 \%$ of respondent choose not to become accountpreneurs or public accountant but they prefer to be other profession such as: finance, teaching, management accounting, government employee and banker, consultant, tax area and others. Other profession consist of many various profession. It looks big portion or big percentage but this is actually divided by many profession as already mentioned above.

For the second part of the research that is pooling the opinion regarding what skills really needed by accounting students to support their future career. The research revealed as follows:

Based on the data in the table 4 most accounting students choose Adaptability skill as the most skill needed by most students 239 (58\%) votes, followed by communication skill with $223(54.3 \%)$ votes, third skill is able to operate accounting software with $221(53.8 \%)$ votes, rank four is data analytics skill (skill 4) with 204 (49.6\%) votes, and lastly English skill with $184(44.8 \%)$ votes.

This skill preference needed by students is really understandable, since in the future accounting role will become more change with other information technology competence and internet of things then accounting students should be adaptive with their business environment. As well as they should be able to communicate with other people from around the world and combine their competency with accounting software and data analytics.

\section{CONCLUSION}

Based on the results and discussion in this study, the following conclusions can be drawn: (1) accounting students in Greater Jakarta area are quite interested in becoming accountpreneurs and public accountant. One out of four they are willing to become accountpreneur and almost one out of four they are willing to become public accountant. However other professions are still attractive for accounting students.

Secondly, for the skills needed by accounting students to support for their future career that is adaptability skill, communication skill, able to operate accounting software skill, data analytics skill, and English skill are very understandable since accounting influenced by the information technology advancement, business world become borderless, competency must be improved and synergized with other field.

Based on the findings of the research the author recommend to the University to prepare more entrepreneurship course and incubation for accounting students in order to prepare their future career. As well as University should prepare those five skilled which they are needed by students in their future career.

\section{REFERENCES}

1. Altinay, L., Madanoglu, M., Daniele, R., \& Lashley, C. (2012). The influence of family tradition and psychological traits on entrepreneurial intention. International Journal of hospitality management, 31(2), 489-499.

2. American Psychological Association. (2012). Guidelines for Psychological Practice with Lesbian, Gay, and Bisexual Clients. American Psychologist, 67(1), 10-42. doi: 10.1037/a0024659.

3. Anna, A. L., Chandler, G. N., Jansen, E., \& Mero, N. P. (2000). Women business owners in traditional and non-traditional industries. Journal of Business venturing, 15(3), 279-303.

4. Ariyanto, D. P., \& Wiratno, A. (2013). The Influence of Capital and Accounting Science Understanding of The Interests of Students To Entrepreneurship (Case Study of a Student Accounting Jenderal Soedirman University). Sustainable Competitive Advantage (SCA), 2(1).

5. Bidin, Z., Mohd Shamsudin, F., \& Othman, Z. (2012). Applying the theory of planned behavior on entrepreneurial intent among Malay accounting students in Malaysia. International Journal of ASEAN, 1(1), 49-60. 
6. Camelo-Ordaz, C., Diánez-González, J. P., \& Ruiz-Navarro, J. (2016). The influence of gender on entrepreneurial intention: The mediating role of perceptual factors. BRQ Business Research Quarterly, 19(4), 261-277.

7. Carr, J. C., \& Sequeira, J. M. (2007). Prior family business exposure as intergenerational influence and entrepreneurial intent: A theory of planned behavior approach. Journal of business research, 60(10), 1090-1098.

8. Carter, N. M., Gartner, W. B., Shaver, K. G., \& Gatewood, E. J. (2003). The career reasons of nascent entrepreneurs. Journal of Business Venturing, 18(1), 13-39.

9. Chotimah, C. (2014). Pendidikan kewirausahaan di pondok pesantren sidogiri pasuruan. INFERENSI: Jurnal Penelitian Sosial Keagamaan, 8(1), 114-136.

10. Dary, A. W., \& llyas, F. (2017). Pengaruh Gender, Penghargaan Finansial and Pertimbangan Pasar Kerja Terhadap Minat Mahasiswa Akuntansi Untuk Berkarir Menjadi Akuntan Publik and Non Akuntan Publik. Jurnal Akuntansi, 7(1), 51-60.

11. Delgado, M. V. M., \& Valencia, E. Entrepreneurial Status of the Students of The Bachelors In Administration And Accounting of The University of Sonora In Mexico.

12. Douglas, E. J., \& Shepherd, D. A. (2002). Self-employment as a career choice: Attitudes, entrepreneurial intentions, and utility maximization. Entrepreneurship theory and practice, 26(3), 81-90.

13. Fatoki, O. (2014). Parental and gender effects on the entrepreneurial intention of university students in South Africa. Mediterranean Journal of Social Sciences, 5(7), 157.

14. GARCÍA, F. J. F., \& CAÑIZARES, S. M. S. (2010). Análisis del perfil emprendedor: una perspectiva de género. Estudios de economía aplicada, 28(3), 1-27.

15. Ghozali, I. (2016). Aplikasi Analisis Multivariete Dengan Program IBM SPSS 23. Edisi 8. Semarang: Badan Penerbit Universitas Diponegoro.

16. Hadiyati, E. (2011). Kreativitas and inovasi berpengaruh terhadap kewirausahaan usaha kecil. Jurnal Manajemen and Kewirausahaan (Journal of Management and Entrepreneurship), 13(1), 8-16.

17. Hanif, H., Rakhman, A., \& Nurkholis, M. (2019). The Construction of Entrepreneurial Accounting: Evidence from Indonesia.

18. Hisrich, R., \& Brush, C. (1984). The woman entrepreneur: Management skills and business problems. Journal of small business management, 22(1), 30-37.

19. Hurley, A. E. (1999). Incorporating feminist theories into sociological theories of entrepreneurship. Women in management review.

20. IAPI Learning Center Berdiri, IAPI: Kami Komitmen Tingkatkan Kompetensi Akuntan. (n.d.). Retrieved from https://libguides.library.usyd.edu.au/c.php?g=508212\&p=3476096

21. Ibrahim, S. N. S., Pauzi, N. F. M., Shamsudin, A., Karim, M. S., \& Ahmad, K. (2017). Motivating Factors for Sustainable Accountant Potentials in Malaysia. In SHS Web of Conferences (Vol. 36, p. 00035). EDP Sciences.

22. Jessica, A., Alimbudiono, R. S., \& Pudjolaksono, E. (2019, April). The Role of Accounting Knowledge In Defining The Career of A Public Accountant. In 2nd Padang International Conference on Education, Economics, Business and Accounting (PICEEBA-2 2018) (pp. 88-96). Atlantis Press.

23. Kogan, I., Graham, J., Belmont, Y., \& Bellenger, D. (2018, August). Russian-Speaking Immigrant Motivation to Become an Entrepreneur in the US. In 2018 Engaged Management Scholarship Conference: Philadelphia, PA.

24. Krueger, N. (1993). The impact of prior entrepreneurial exposure on perceptions of new venture feasibility and desirability. Entrepreneurship theory and practice, 18(1), 5-21.

25. Kyndt, E., \& Baert, H. (2015). Entrepreneurial competencies: Assessment and predictive value for entrepreneurship. Journal of Vocational Behavior, 90, 13-25.

26. Lukman Raimi. (2016). Accountpreneur - A Necessity in the Current Recession [PowerPoint slides]. https://slideplayer.com/slide/12646368/.

27. Lyons, P., \& Bandura, R. P. (2016). Entrepreneurial Intentions of Accounting Students. Journal of Business and Entrepreneurship, 28(1), 73. 
28. Machera, R. P., \& Machera, P. C. (2017). Computerised Accounting Software; A Curriculum That Enhances an Accounting Programme. Universal Journal of Educational Research, 5(3), 372-385.

29. McDowall, T., \& Jackling, B. (2010). Attitudes towards the accounting profession: an Australian perspective. Asian Review of Accounting.

30. Nightingale, A. J. (2002). Participating or just sitting in? The dynamics of gender and caste in community forestry. Journal of forest and livelihood vol, 2(1). Nightingale, A. J. (2002). Participating or just sitting in? The dynamics of gender and caste in community forestry. Journal of forest and livelihood vol, 2(1).

31. Nurbaeti, I., Mulyati, S., \& Sugiharto, B. (2019). The Effect of Financial Literacy and Accounting Literacy to Entrepreneurial Intention Using Theory of Planned Behavior Model in STIE Sutaatmadja Accounting Students. JASS (Journal of Accounting for Sustainable Society), 1(01), 1-1.

32. Nurrahmah, S., \& Aisyah, M. N. (2018). ANALYSIS of FACTORS THAT AFFECT ENTREPRENEURSHIP INTEREST IN STUDENTS of ACCOUNTING EDUCATION FACULTY of ECONOMICS YOGYAKARTA STATE UNIVERSITY. Kajian Pendidikan Akuntansi Indonesia, 7(8).

33. Priyatno, Duwi. (2010). Belajar Cepat Olah Data Statistik Dengan SPSS. Jakarta: Penerbit Andi.

34. Reyad, S. M. R., Badawi, S. S., \& Hamdan, A. M. (2018). Entrepreneurship and accounting students' career in the Arab region: Conceptual perspective. The Journal of Developing Areas, 52(4), 283-288.

35. Reyad, S., Badawi, S., \& Hamdan, A. (2020). Assessing the impact of entrepreneurial skills development on self-employment practices amongst Egyptian and Bahraini accounting students in public and private universities. Journal of Islamic Accounting and Business Research.

36. Saeed, S., Muffatto, M., \& Yousafzai, S. Y. (2014). Exploring intergenerational influence on entrepreneurial intention: the mediating role of perceived desirability and perceived feasibility. International Journal of Entrepreneurship and Innovation Management, 18(23), 134-153.

37. Saragih, R. (2017). Membangun usaha kreatif, inovatif and bermanfaat melalui penerapan kewirausahaan sosial. Jurnal Kewirausahaan, 3(2), 26-34.

38. Suprato, D., Dewi, I. I., \& Paulina, C. (2018). English Syllabus for Accounting Students and the Needs of English in Business World. Lingua Cultura, 12(2), 129-134.

39. Timmons, Jeffry A. \& Spinelli, S., Jr. (2008). New Venture Creation. Kewirausahaan untuk Abad 21. Yogyakarta: Andi. (Buku asli New Venture Creation: Entrepreneurship for the 21st Century 6th ed.).

40. Trending Accounting. (2020). Meet Phil Knight, The Richest Accountant In The World. Retrieved from https://www.trendingaccounting.com/2020/09/meet-phil-knight-richestaccountant-in.html.

41. Ulfah, R., Jaharadak, A., \& Khatibi, A. (2019). Motivational factors influencing MSU accounting students to become a certified public accountant (CPA). Management Science Letters, 9(10), 1675-1684.

42. Woodside, J. M., Augustine, F. K., Chambers, V., \& Mendoza, M. (2020). Integrative learning and interdisciplinary information systems curriculum development in accounting analytics. Journal of Information Systems Education, 31(2), 147. 